\title{
Tofu wastewater treatment using contact glow discharge electrolysis method and air injection
}

\author{
Nadira Kamilia Permatasari ${ }^{1, *}$, Widya Pangestika ${ }^{1}$, and Nelson Saksono ${ }^{1}$ \\ ${ }^{1}$ Department of Chemical Engineering, Universitas Indonesia, Depok 16424, Indonesia
}

\begin{abstract}
Tofu wastewater is one of the most dangerous source of environmental pollutants. It is known that the COD of tofu wastewater can reach $8000 \mathrm{mg} / \mathrm{L}$. Contact Glow Discharge Electrolysis (CGDE) method is an effective method in degrading complex pollutants contained in tofu wastewater, due to its ability to produce large quantities of $\mathrm{OH}$ radicals. This study aims to test the ability of the CGDE method in degrading the tofu wastewater by the addition air injection. In this method, several variations were made to determine the optimal airflow rate and initial concentration of tofu wastewater. Tofu wastewater degradation reached $73 \%$ for 120 minutes, with the final value of COD is $425 \mathrm{mg} / \mathrm{L}$ and BOD is $447 \mathrm{mg} / \mathrm{L}$. Maximum conditions are obtained by using airflow rate $2.5 \mathrm{lpm}$, temperature $50^{\circ} \mathrm{C}$, and initial concentration of tofu wastewater is $2000 \mathrm{ppm}$. The addition of air injection with airflowrate $2.5 \mathrm{lpm}$ is able to reduce energy consumption by $37 \%$. The results show that CGDE with air injection has the potential to degrade pollution parameter in tofu wastewater.
\end{abstract}

\section{Introduction}

Today, the tofu industry has become one of the most widespread domestic industries in Indonesia. Data from Badan Pusat Statistik (BPS) of Indonesia stated that the number of average tofu consumption per capita in Indonesia in 2016 is $0.151 \mathrm{~kg} /$ week. This amount of consumption increased from previous years.

But in the production process, the tofu industry produces liquid and solid waste. Solid waste in the form of dregs of tofu has been overcome by utilizing it as an animal feed ingredients. Besides, tofu wastewater can cause severe pollution because it contains high organic content. Several studies have shown that the tofu wastewater has BOD content of about 5000-10000 mg/l, the concentration of COD (Chemical Oxygen Demand) between $7000-10000 \mathrm{mg} / \mathrm{l}$ and $\mathrm{pH}$ ranges from 4 to 5 [1].

Wastewater is discharged directly into waters such as rivers and others. The waste will seep into shallow groundwater that can contaminate the wells because they are not processed or have not been optimally processed. The presence of high organic pollutants in tofu wastewater increases the parameters of BOD, COD, ammonia, nitrite and nitrate as well as suspended solids in the water. According to PERMEN LH Number 15 Year 2008 regarding waste water quality standard for soybean processing business, BOD content limit $150 \mathrm{mg} / \mathrm{l}$ and COD $300 \mathrm{mg} / \mathrm{l}$. Because of that, it is required an effective treatment to achieve the standard quality that has been set.

To overcome the problems caused by tofu wastewater, the proposed method is Contact Glow Discharge Electrolysis (CGDE) with the addition of air injection. CGDE is a method of plasma electrolysis, generated by direct current (DC) between the electrode and the surrounding electrolytic surface. CGDE stems from ordinary electrolysis (Faraday). After Faraday's electrolysis takes place, the operating voltage is increased to a very high level until plasma is formed. Plasma is an ionized gas due to electromagnetic discharges and produces hydroxyl radicals $(\mathrm{OH})$ in much higher quantities than other methods [2]. CGDE can decompose water molecules into $\bullet \mathrm{OH}$ and $\bullet \mathrm{H}$. Production of $\bullet \mathrm{OH}$ as well as $\mathrm{OH} \bullet$ interactions with these wastewater affect the effectiveness of CGDE in degrading waste [3].

The addition of electrolytes to the CGDE process can increase the conductivity of the solution, and trigger an increase in the amount of hydroxyl radical production. The $\mathrm{Na}_{2} \mathrm{SO}_{4}$ electrolyte is chosen because it is an inert electrolyte that will not disturb the active species of the plasma. The optimum concentration of $\mathrm{Na}_{2} \mathrm{SO}_{4}$ in plasma electrolysis method was $0.02 \mathrm{M}$ [2]. In addition, in the CGDE zone required a high voltage to achieve stability. For degradation of wastewater on the addition of $\mathrm{Na}_{2} \mathrm{SO}_{4}$ electrolyte, a voltage of $700 \mathrm{~V}$ shows the best results in terms of waste degradation and energy consumption [4].

The use of air injections may affect plasma activity and increase the production of free radicals or reactive molecules [5]. It provides good process efficiency, in terms energy consumption and increased $\mathrm{OH} \bullet$ production that play a role in degrading waste water. Therefore, a combination of methods of CGDE and air injection is a promising method.

This study uses CGDE method with the addition of air injection, which is intended to test its effectiveness in terms of energy consumption, $\mathrm{OH} \cdot$ production amount and Chemical Oxygen Demand (COD) value in tofu waste water. It is expected that the results of this research can be an effective and efficient method of processing waste water.

\footnotetext{
* Corresponding author: nadirakamilia@hotmail.com
} 


\section{Materials and method}

The experimental set-up used in this research is the Contact Glow Discharge Electrolysis (CDGE) Reactor. Where the reactor used is a batch reactor system surrounded by a cooling jacket using cooling water circulation. The schematic diagram of the experimental setup of plasma electrolysis can be seen at Fig.1

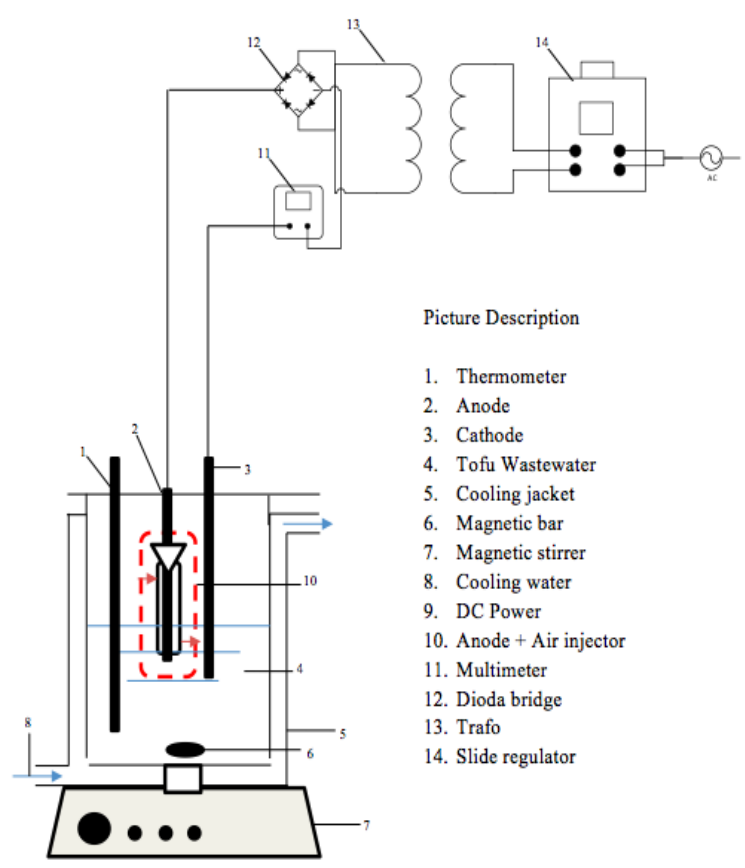

Fig. 1. The schematic diagram of experimental setup for plasma electrolysis

Before testing the degradation of tofu wastewater with the CGDE reactor, a reactor performance was tested first. The next step is characteristic test. In testing the characteristics of current and voltage, the electrolit used in the CGDE process is $\mathrm{Na}_{2} \mathrm{SO}_{4} 0.02 \mathrm{M}$. This test was conducted to determine the value of voltage range for plasma formation on CGDE process.

Furthermore, the data taken are tofu wastewater degradation with variations of initial concentration and air flowrate injection. Hydrogen Proxide $\left(\mathrm{H}_{2} \mathrm{O}_{2}\right)$ production test was conducted with variation of air flowrate injection. Hydrogen Peroxide produced during CGDE process were measured using Permanganometry titration. The study is conducted for 2 hours, and sampling at minute $0,10,20$, $30,40,60,90$ and 120 .

\section{Results and discussion}

The results obtained during the study were discussed and analyzed which can be explained as follows

\subsection{Characteristic curve on CGDE}

Characterization of current and voltage in this study was conducted at a voltage of $0-750 \mathrm{~V}$ with the addition of air injection in high flow rate variation $(2.5 \mathrm{lpm})$, low flow rate $(1.3 \mathrm{lpm})$ and without addition of air injection $(0$ $\mathrm{lpm})$. The temperature of the test is maintained at $\pm 50^{\circ} \mathrm{C}$.

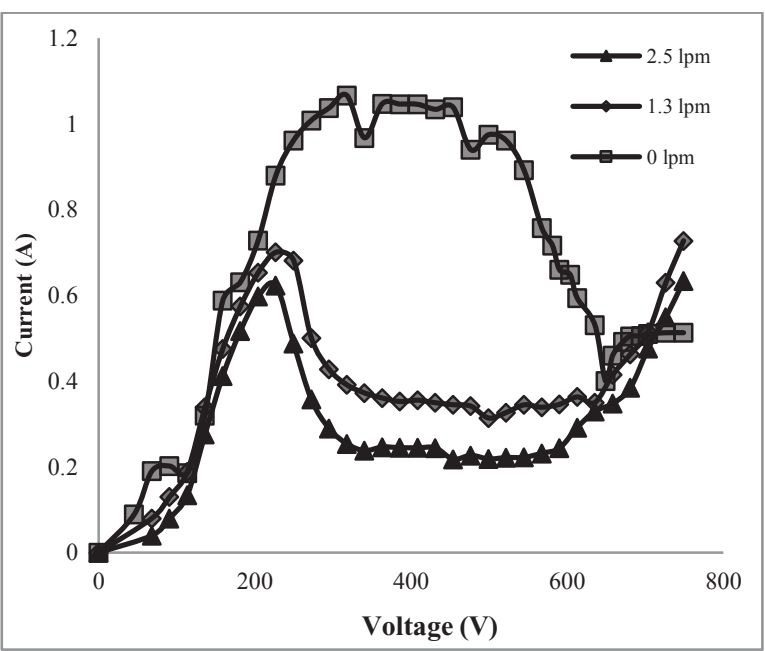

Fig. 2. The voltage-current characteristic curve with variation of air injection flow rate

Figure 2 shows the profile of the resulting voltagecurrent curve with varying airflow injection rate. From the characteristic curve, it can be seen that the value of $V_{B}$ (breakdown voltage) and $\mathrm{V}_{\mathrm{D}}$ (discharge voltage) in the presence of additional air injection is smaller than without the addition of air injection.

It can be seen in Table 1, when there are addition of air injection, the current value is smaller than without the addition of air injection. It can be concluded that the increase in the rate of air injection flow rate, the energy needed will be smaller.

Table 1. Characterization Curve in Air Injection Flowrate Variation

\begin{tabular}{|c|c|c|c|c|c|c|}
\hline \multirow{2}{*}{$\operatorname{lpm}$} & \multicolumn{3}{|c|}{ Breakdown Voltage $\left(\mathrm{V}_{\mathrm{B}}\right)$} & \multicolumn{3}{|c|}{ Discharge Voltage $\left(\mathrm{V}_{\mathrm{D}}\right)$} \\
\cline { 2 - 7 } & $\begin{array}{c}\mathrm{V} \\
\text { (Volt) }\end{array}$ & $\mathrm{I}(\mathrm{A})$ & $\mathrm{KJ}$ & $\begin{array}{c}\mathrm{V} \\
\text { (Volt) }\end{array}$ & $\begin{array}{c}\mathrm{I} \\
(\mathrm{A})\end{array}$ & KJ \\
\hline 2,5 & 227 & 0,62 & 141,54 & 477 & 0,22 & 108,16 \\
\hline 1,3 & 227 & 0,70 & 159,02 & 499 & 0,31 & 156,83 \\
\hline 0 & 318 & 1,06 & 339,04 & 649 & 0,40 & 259,68 \\
\hline
\end{tabular}

The addition of air injection can lower the electrical resistance because the gas has a lower dielectric constant than the solution. The dielectric constant is related to the ability of a material to resist high voltage. When the dielectric constant is low, plasma is more easily formed so that the required energy is also lower [6].

\subsection{Hydrogen peroxide $\left(\mathrm{H}_{2} \mathrm{O}_{2}\right)$ production on CGDE process}

\subsubsection{Effect of air injection flow rate}

This stage aims to determine the performance of the CGDE method with the addition of air injections to produce hydrogen peroxide as an indicator of the presence 
of hydroxyl radicals. The hydroxyl radical is the main active species used to degrade or decrease the COD value of the tofu wastewater. $\mathrm{OH}$ radicals have a very short residence time, which is about $3.7 \times 10^{-9}$ seconds [7]. Therefore, to know the production of $\mathrm{OH}$ can be calculated by measuring the concentration of $\mathrm{H}_{2} \mathrm{O}_{2}$ formed. Quantification of $\bullet \mathrm{OH}$ is performed using $0.02 \mathrm{M}$ $\mathrm{Na}_{2} \mathrm{SO}_{4}$ electrolyte solution. $\cdot \mathrm{OH}$ is likely to react with each other to form hydrogen peroxide $\left(\mathrm{H}_{2} \mathrm{O}_{2}\right)$ as follows

$$
2 \cdot \mathrm{OH} \leftrightarrow \mathrm{H}_{2} \mathrm{O}_{2}
$$

The method used to quantify Hydrogen Peroxide is the Permanganometric Titration Method. The variations performed in this study were $2.5 \mathrm{lpm}, 1.3 \mathrm{lpm}$ and $0 \mathrm{lpm}$. The observations were done without the tofu wastewater. Based on Figure 3, the results obtained at 120 minutes, in high flow rate injection or $2.5 \mathrm{lpm}$ resulted in $\mathrm{H}_{2} \mathrm{O}_{2}$ production with the greatest number which is $12.60 \mathrm{mmol}$. Seen on the graph that between high flow rate air injection and low flow rate does not show a significant difference. Based on the graph, the production of $\mathrm{H}_{2} \mathrm{O}_{2}$ increases with time. This indicates that there is accumulation of $\mathrm{H}_{2} \mathrm{O}_{2}$ production from time to time. This increase in $\mathrm{H}_{2} \mathrm{O}_{2}$ levels occurs because the reaction in the CGDE reactor generates a large amount of $\mathrm{OH}$ radicals, and later recombinates with each other to form $\mathrm{H}_{2} \mathrm{O}_{2}$. In the solution, there is no other compound that can be oxidized by $\mathrm{OH}$ radical compounds, causing these compounds to accumulate in large quantities and turning into $\mathrm{H}_{2} \mathrm{O}_{2}$ compounds [8]

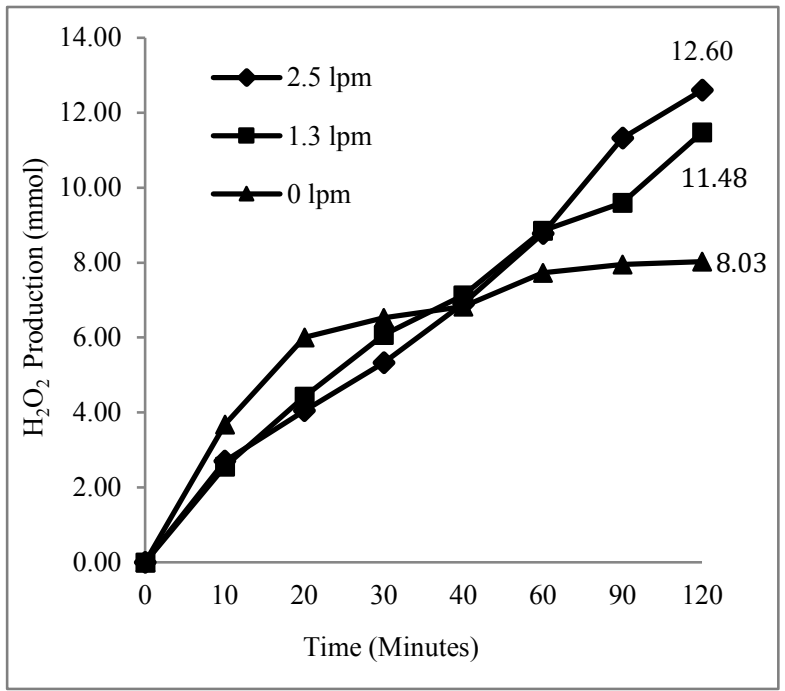

Fig. 3. The effect of air injection flow rate on $\mathrm{H}_{2} \mathrm{O}_{2}$ production

The injected air has a composition of $79 \%$ nitrogen and $21 \%$ oxygen. The main reactions that occur between oxygen and nitrogen with hydroxyl radicals are as follows [9] :

$$
\begin{aligned}
& \mathrm{e}^{-}+\mathrm{O}_{2} \rightarrow \mathrm{O} \bullet+\mathrm{O} \bullet+\mathrm{e}^{-} \\
& \mathrm{O} \bullet+\mathrm{H}_{2} \mathrm{O} \rightarrow \bullet \mathrm{OH}+\bullet \mathrm{OH} \\
& \mathrm{e}^{-}+\mathrm{H}_{2} \mathrm{O} \rightarrow \mathrm{H} \bullet+\cdot \mathrm{OH}+\mathrm{e}^{-}
\end{aligned}
$$

Based on the above equation, it is known that $\mathrm{O}_{2}$ will react with electrons and produce $\mathrm{O} \bullet$. Furthermore, $\mathrm{O} \bullet$ will react with $\mathrm{H}_{2} \mathrm{O}$ and generate $\mathrm{OH} \bullet$. This results in an increase in the production value of $\mathrm{OH} \bullet$, which is quantified with $\mathrm{H}_{2} \mathrm{O}_{2}$ in addition to air injection.

Table 2. The effect of air flow rate variation on energy, $\mathrm{H}_{2} \mathrm{O}_{2}$ production, and specific energy

\begin{tabular}{|c|c|c|c|}
\hline $\begin{array}{c}\text { Flow Rate } \\
(\mathrm{lpm})\end{array}$ & $\begin{array}{c}\text { Energy } \\
(\mathrm{kJ})\end{array}$ & $\begin{array}{c}\mathrm{H}_{2} \mathrm{O}_{2} \\
\text { Production } \\
(\mathrm{mmol})\end{array}$ & $\begin{array}{c}\text { Energy } \\
(\mathrm{kJ} / \mathrm{mmol})\end{array}$ \\
\hline 2,5 & 489,52 & 12,60 & 38,85 \\
\hline 1,3 & 678,01 & 11,48 & 59,09 \\
\hline 0 & 1365,55 & 8,03 & 170,16 \\
\hline
\end{tabular}

Table 2 shows that in addition to air injection, the resulting specific energy is lower. There is a significant difference in conditions with the addition of air injection and without the addition of air injection. This is because the addition of air injection can accelerate the process of plasma stabilization because the plasma is an ionized gas that is easier to form on the gas media than liquid.

\subsection{Contact glow discharge electrolysis in tofu wastewater}

\subsubsection{Effect of air injection flowrate}

After conducting the voltage-current characterization and $\mathrm{H}_{2} \mathrm{O}_{2}$ production tests, a CGDE method was conducted on the degradation of tofu wastewater. This stage aims to obtain the optimum conditions of the CGDE method in lowering the COD value of tofu wastewater and find the lowest energy required in the process.

Effect of airflow injection variation on degradation of tofu wastewater was done with initial waste concentration of $\pm 2000 \mathrm{ppm}$, addition of $\mathrm{Fe}^{2+} 60 \mathrm{ppm}$, addition of 0.02 $\mathrm{M} \mathrm{Na}_{2} \mathrm{SO}_{4}$, anode depth of $1.5 \mathrm{~cm}$ and operating condition at $700 \mathrm{~V}$.

In Figure 4, it can be seen the number of degradation percentage is increasing. The increasing value of degradation percentage over time indicates that, if the process continues beyond 2 hours then there is still a possibility of COD removal. 


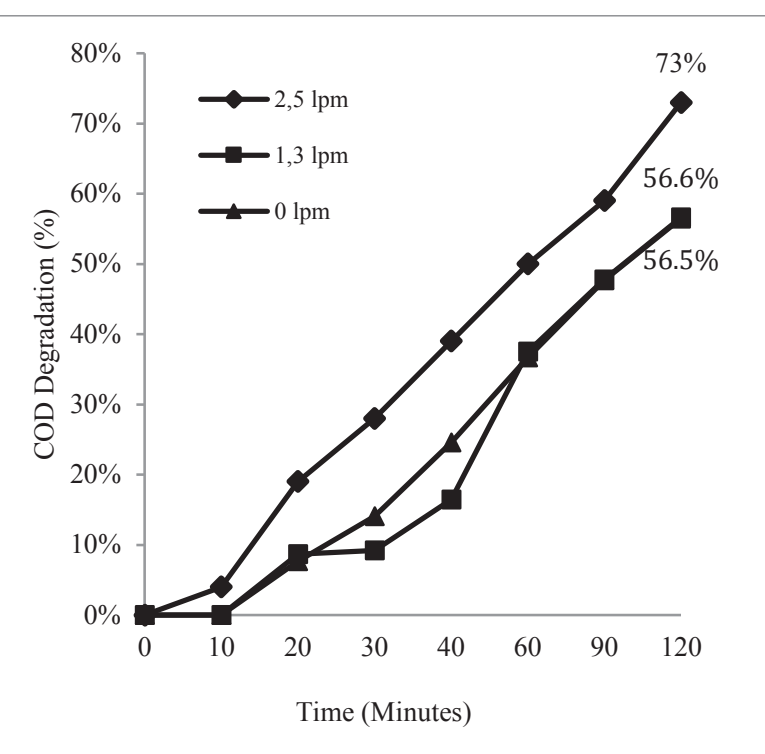

Fig 4. The effect of air injection flowrate on COD Degradation

Based on the reaction 2, $\mathrm{O}_{2}$ will produce an $\mathrm{O}$ radical where the oxidation number of $\mathrm{O}$ is quite high after the $\mathrm{OH}$ radical. The oxidation values of $\mathrm{OH}, \mathrm{O}, \mathrm{O}_{3}$ and $\mathrm{H}_{2} \mathrm{O}_{2}$ radicals are respectively $2.8 ; 2.42 ; 2.07$; and 1.78 [5]. These values indicate that $\cdot \mathrm{O}$ has the second highest oxidation number after the $\mathrm{OH}$ radical which increases the effectiveness of waste degradation. It is known that the addition of air injections will increase the number of active species such as $\mathrm{H}_{2} \mathrm{O} \bullet$ and $\mathrm{O} \bullet$. Active species $\mathrm{H}_{2} \mathrm{O}$ • has an oxidation potential of $1.06 \mathrm{~V}$ while $\mathrm{O} \cdot$ is $2.42 \mathrm{~V}$ [11]. Although the oxidation strength of the species is not as large as that of a radical $\mathrm{OH}$, the active species can help the pollutant degradation process in the tofu waste water.

Table 3. The effect of air flow rate variation on energy consumption and COD degradation

\begin{tabular}{|c|c|c|c|}
\hline $\begin{array}{c}\text { Flowrate } \\
(\mathrm{lpm})\end{array}$ & $\begin{array}{c}\text { Energy } \\
(\mathrm{kJ})\end{array}$ & $\begin{array}{c}\text { COD } \\
\text { Degradatio } \\
\mathrm{n} \\
(\mathrm{ppm})\end{array}$ & $\begin{array}{c}\text { Specific } \\
\text { Energy } \\
(\mathrm{kJ} / \mathrm{mmol})\end{array}$ \\
\hline 2,5 & 2101,60 & 1124,30 & 89,72 \\
\hline 1,3 & 2421,32 & 1097,30 & 105,92 \\
\hline 0 & 3282,32 & 1095,95 & 143,76 \\
\hline
\end{tabular}

From Table 3, it can be seen that the addition of air injection can decrease the energy consumption required in the process. With the addition of air injection in the CGDE process, it can facilitate the formation of plasma because the dielectric strength of the gas is lower than the solution so that at lower plasma stress is already formed and the required energy becomes smaller [6].

\subsubsection{Effect of initial concentration}

Further tests were conducted with variation of initial concentration of tofu wastewater. Initial waste concentrations were varied in concentrated waste $( \pm 7000$ ppm), $\pm 4000 \mathrm{ppm}$, and $\pm 2000 \mathrm{ppm}$. Dilution is done to get the concentration to be achieved. The observation period was 2 hours. The percentage of degradation or removal of COD with respect to time with the influence of initial concentration of waste is shown in Figure 5.

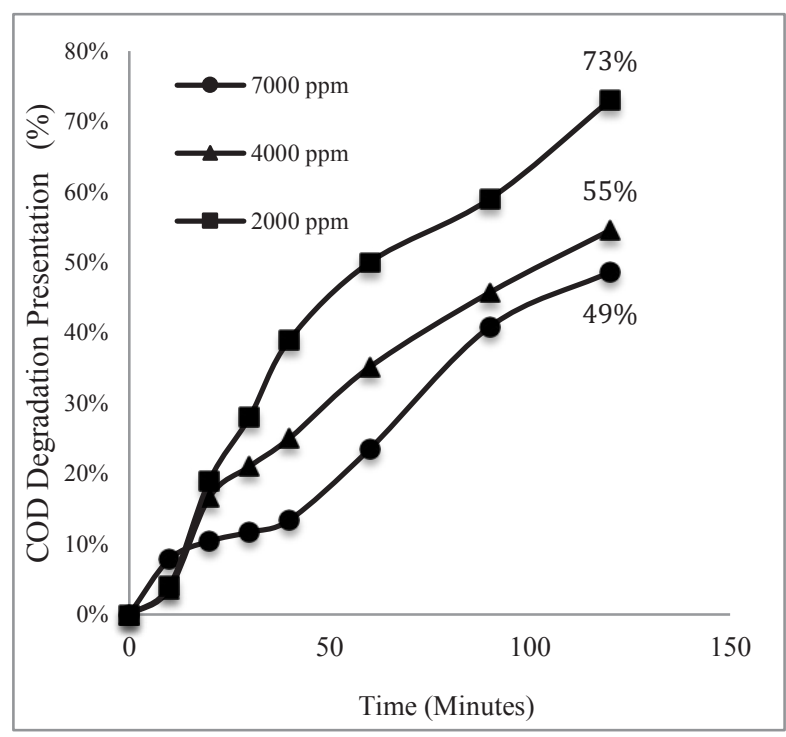

Fig 5. The effect of initial concentration on COD Degradation

When the initial reactants are oxidized into intermediate products, these intermediate compounds will also play a role in the oxidation reaction. The higher the initial concentration of the reactants, the more intense the competition between the initial reactants and intermediate products with active species. Finally, the percentage of degradation decreases if the initial concentration of waste is increased [12].

In Figure 5, there is still a trend of increasing degradation percentage over time. If the time of the CGDE process continues beyond 120 minutes, then the tofu wastewater will be further degraded as the $\mathrm{OH}$ radicals will continue to react with the wastewater as long as the concentrations of available waste are numerous. The higher the initial concentration of the waste, the more complex molecules that are difficult to degrade, the time required for COD removal will also be longer.

Based on Table 4, The largest specific energy in the 120th minute is the CGDE process with the initial concentration of waste $\pm 2000 \mathrm{ppm}$ which is $89.72 \mathrm{~kJ} /$ mmol.

Table 4. The effect of air flow rate variation on energy consumption and COD degradation

\begin{tabular}{|c|c|c|c|}
\hline $\begin{array}{c}\text { Initial } \\
\text { Concentration } \\
(\mathrm{ppm})\end{array}$ & $\begin{array}{c}\text { Energy } \\
(\mathrm{kJ})\end{array}$ & $\begin{array}{c}\text { COD } \\
\text { Degradation } \\
(\mathrm{ppm})\end{array}$ & $\begin{array}{c}\text { Specific } \\
\text { Energy } \\
(\mathrm{kJ} / \mathrm{mmol})\end{array}$ \\
\hline \pm 7000 & 2386,23 & 3487,90 & 32,84 \\
\hline \pm 4000 & 2349,16 & 2290,60 & 49,23 \\
\hline \pm 2000 & 2101,59 & 1124,30 & 89,72 \\
\hline
\end{tabular}

The energy $(\mathrm{kJ})$ required for each process in each relative concentration is not very different as it is measured on the same variable and time. 


\subsection{BOD Degradation in Optimum Condition}

In this study, the BOD value was compared between the filtered initial tofu wastewater, and the tofu wastewater that has been through the CGDE process with air injections for 120 minutes. The wastewater used has an initial concentration of $\pm 2000 \mathrm{ppm}$, with the addition of $\mathrm{Na}_{2} \mathrm{SO}_{4}$ of $0.02 \mathrm{M}$ and $\mathrm{Fe}^{2+}$ of $60 \mathrm{ppm}$. Temperatures were maintained at around $50^{\circ} \mathrm{C}$ and with $2.5 \mathrm{lpm}$ air injection.

Table 5. BOD Test Result in Tofu Wastewater

\begin{tabular}{|c|c|c|}
\hline Parameter & $\begin{array}{c}\text { Initial Concentration } \\
(\mathrm{mg} / \mathrm{L})\end{array}$ & $\begin{array}{c}\text { Final Concentration } \\
(\mathrm{mg} / \mathrm{L})\end{array}$ \\
\hline $\mathrm{BOD}_{5}$ & 658 & 447 \\
\hline
\end{tabular}

The high concentration of BOD in tofu wastewater is caused by the high protein substance contained in the tofu wastewater. So that the amount of oxygen needed by microorganisms in the waters to degrade the waste is very large. Liquid wastewater that has been through the CGDE process with the addition of air injection for 120 minutes under optimal conditions, resulting in a BOD value of 447 $\mathrm{mg} / \mathrm{L}$ as seen on Table 5 .

\section{Conclusion}

Experiments have been conducted to degrade tofu wastewater through CGDE process. The results show that the hydroxyl radical production is higher during the CGDE process. COD Value in Tofu wastewater was decreased in higher number of air injection flow rate and lower number of initial concentration. The optimum result obtained on the removal of COD value of tofu wastewater in 120 minutes, using $0.02 \mathrm{M} \mathrm{Na}_{2} \mathrm{SO}_{4}$ solution, $700 \mathrm{~V}$ voltage, $2 \mathrm{~cm}$ anode depth and initial waste concentration $\pm 2000 \mathrm{ppm}$. The percentage of COD removal was $73 \%$, and eliminated the concentration of COD by $1124.3 \mathrm{ppm}$, with energy consumption of $2101.6 \mathrm{~kJ}$ and a specific energy of $89.72 \mathrm{~kJ} / \mathrm{mmol}$. CGDE process with addition of air injection resulted COD final value of $425 \mathrm{mg} / \mathrm{L}$ and BOD value of $447 \mathrm{mg} / \mathrm{L}$.

The research was funded by "Hibah Publikasi Terindeks Internasional Untuk Tugas Akhir Masiswa Universitas Indonesia 2018" from Directorate Research and Community Service Universitas Indonesia. The author declare no competing interests or any conflicts of financial interests. Contract no. 2499/UN2.R3.1/HKP.05.00/2018.

\section{References}

1. Abineri, H.S., Sato A., Utomo, P. Pengolahan limbah tahu secara anaerobik-aerobik kontinu. Seminar Nasional Sains dan Teknologi Terapan 3, 1 (2015)

2. Saksono, N., Nugraha, I., Gozan, M., \& Bismo, S. Plasma formation energy and hydroxyl production on contact glow discharge electrolysis. International Journal of Arts \& Sciences, 7(3), 71. (2014)

3. Saksono, N., Adiwidodo, B. P., Karamah, E. F., \& Kartohardjono, S. Contact glow discharge electrolysis system for treatment of wastewater containing ammonia. Journal of Environmental Science and Technology 6 (1), 41-49. (2013)

4. Seratri, R. T. Degradation of phenol in liquid waste by electrolysis plasma method (CGDE) using $\mathrm{Na}_{2} \mathrm{SO}_{4}$ electrolytes. Depok: Chemical Engineering Program, Faculty of Engineering, University of Indonesia. (2013)

5. Ruma, Habib, M.A., Sakugawa, T. Treatment of Wastewater by Underwater Discharge in Gas Bubbling Water. Journal of Renewable Energy and Environmental Engineering 3,3. (2015)

6. Ahmed M W, Suresh R, Yang J K, Choi S and Lee H J. effect of water conductivity on the generation of $\mathrm{OH}$ radicals in high frequency underwater capillary discharge Int. J. Renew. Energy Environ. Eng. 428. (2016)

7. Jiang, B., Zheng, J., Qiu, S., Wu, M., Zhang, Q., Yan, Z., \& Xue, Q. Review on electrical discharge plasma technology for wastewater remediation. Chemical Engineering Journal, 236, 348-368. (2014)

8. Jin, X., Wang, X., Yue, J., \& Cai, Y. The Effect of Electrolysis Constituents on Contact Glow Discharge Electrolysis. Electrochimica Acta, 56, 925-928. (2010).

9. Yasuoka, K. dan Sato, K. Development of Repetitive Pulsed Plasmas in Gas Bubbles for Water. International Journal of Plasma Environmental Science and Technology, 3(1), 22-27. (2010).

10. Saito Genki, Yuki Nakasugi, and Tomohiro Akiyama. Generation of solution plasma over a large electrode surface area. Journal Of Applied Physics 118, 023303. (2015).

11. Augusto, O., \& Sayuri, M. Oxygen Radicals and Related Species. Free Radical Biomedicine, Vol 1. ISBN: 978-1-61209-773-2. (2011).

12. Gao, J., Wang, X., Hu, Z., Deng, H., Hou, J., Lu, X. \& Kang, J. (2003). Plasma degradation of dyes in water with contact glow discharge electrolysis. Water Research, 37, 267-272. 